\title{
Brigitta Helbig-Mischewski
}

\section{Między omnipotencją a niemocą, gloryfikacją a denuncjacją.}

\section{O rozpadzie "porządku Ojca" i masochizmie w twórczości Brunona Schulza}

Bruno Schulz, autor dwóch autobiograficznych tomów prozatorskich, w których konstelacja postaci ograniczona została niemal wyłącznie do rodzinnego kręgu narratora, należy do nielicznego grona polskojęzycznych pisarzy znanych także poza granicami kraju. Jego intymna proza, kreująca prywatną, „rodzinną mitologię”, wydaje się z dzisiejszej perspektywy paradoksalnie bardziej uniwersalna i międzynarodowa niż literackie „pomniki” obciążone społeczno-polityczną misją. Obydwa jego tomy prozatorskie, Sklepy cynamonowe (1934) oraz Sanatorium pod klepsydrą (1937) uchodzą w świecie za godne polecenia wszystkim miłośnikom prozy fantastycznej i groteskowej. Wielu zagranicznych badaczy zwracało uwagę na związki Schulza $z$ apokaliptyczną literaturą monarchii habsburskiej (Kafka, Musil, Rilke), a także z niemiecką literaturą epoki wilhelmińskiej i Republiki Weimarskiej (Mann, Hesse), przesyconą mitologiczno-matriarchalnymi tęsknotami, oraz sytuowało go w kontekstach kulturowego krajobrazu mitogennej, multietnicznej Galicji (Sader Masoch, Joseph Roth). Znane są również grafiki Schulza, wielokrotnie interpretowane jako wyraz idolatrii kobiecości. Schulz - jak wiadomo obsesyjnie, często w ekspresjonistycznej manierze, portretował nagą dominę, otoczoną czołgającymi się, zgiętymi w pokorze adoratorami, pożerającymi i „konstruującymi” ją jednocześnie voyerystyczno-pożądliwymi spojrzeniami. Na kilku rysunkach kobiecą postać prześladuje procesja gapiących się na nią mężczyzn o gigantycznie wielkich głowach ${ }^{1}$.

Bruno Schulz, nieśmiały i powściągliwy nauczyciel rysunku, a zarazem jeden $\mathrm{z}$ najważniejszych przedstawicieli polskiej awangardy urodził się w 1892 w Drohobyczu, na galicyjskiej peryferii Habsburskiej Rzeszy, jako syn żydowskiego handlarza suknem i tam zginął w 1942, rozstrzelany na ulicy przez oficera Gestapo. Żył w świecie dotkniętym głębokim kryzysem, „w okresie, gdy - jak pisze Artur Sandauer, jeden z pierwszych krytyków Schulza - w błocie i nędzy polskich miasteczek dogory-

1 Por. B. Schulz, Das graphische Werk, München 2000. 
wała najbliższa mu społecznośćn". Mowa o dramatycznej sytuacji gospodarczej ludności żydowskiej Galicji początków XX wieku, będącej skutkiem spóźnionej industrializacji kraju. Żył w świecie dekadenckiego patriarchatu, naznaczonego poczuciem wyczerpania oraz matriarchalnymi tęsknotami i urojeniami, w świecie upadku hegemonii cesarzy i carów w środkowej i wschodniej Europie, a także - jak to (przesadnie) określił Dieter Lenzen - „przesunięcia ojca na peryferyjną pozycję w strukturze rodziny" ${ }^{3}$ oraz traumatyzującej emancypacji kobiet i kryzysu wiary ${ }^{4}$. Był to również okres cywilizacyjnego optymizmu w kulturze polskiej, jednakże ten dyskurs nie miał wpływu na prozę Schulza.

Brzemiennym w skutkach doświadczeniem młodego Schulza było bankructwo ojca, które stanie się centralnym motywem jego twórczości. Miało ono związek $z$ ekspansją masowej produkcji i konsumpcji, jak również z opanowaniem regionu przez przemysł naftowy, co wyparło wszelkie formy indywidualnego, zrytualizowanego handlu prywatnego. Jednakże literacko przetworzony dramat rodzinny wybiega znacznie poza aspekt gospodarczy i staje się emblematem wstrząsającego kryzysu żydowsko-chrześcijańskiej, patriarchalnej oraz logo- i androcentrycznej kultury, jej mitów i modeli objaśniania świata. Proza Schulza da się czytać jako eksperyment dość szczególny w literaturze polskiej, unikającej raczej podobnych konfrontacji ojca i syna. Polega on $\mathrm{z}$ jednej strony na retrospektywnym dowartościowaniu nieudanej egzystencji „autobiograficznego" ojca, z drugiej zaś, biorąc za punkt wyjścia tę właśnie figurę, na wizyjnym zainscenizowaniu upadku określonej formacji kulturowej spoza obszaru polskich uwikłań narodowych, której ważnym elementem była patriarchalna tradycja wschodnioeuropejskiego żydostwa. Przy czym upadek ten jest przedmiotem skargi i fascynacji jednocześnie.

Sięgając do znanych teorii feministycznych na temat kulturowych fantazmatów kobiecości i nakładania się opozycji ducha i ciała na dualizm płci (Irigaray, Bovenschen) oraz opierając się na koncepcji masochizmu Gillesa Deleuze ${ }^{5}$ chcę pokazać, jak masochistyczna koncepcja

${ }^{2}$ A. Sandauer, Rzeczywistość zdegradowana. Rzecz o Brunonie Schulzu, Warszawa 1964 , s. 32. Za odkrywcę, zasłużonego znawcę i biografa, a przede wszystkim gorącego "wyznawcę" Schulza uważany jest Jerzy Ficowski.

${ }^{3}$ D. Lenzen, Vaterschaft. Vom Patriarchat zur Alimentation, Reinbek 1981.

${ }^{4}$ Por. I. Stephan, C. Benthien, Männlichkeit als Maskerade. Kulturelle Inszenierungen vom Mittelalter bis zur Gegenwart, Köln 2003, s. 161 oraz W. Erhar, B. Hermann, Wann ist der Mann ein Mann? Zur Geschichte der Männlichkeit, Stuttgart, Wei$\operatorname{mar} 1997$, s. 10.

5 G. Deleuze, Sacher Masoch und der Masochismus, w: L. von Sacher-Masoch, Venus im Pelz. Mit einer Studie über den Masochismus von Gilles Deleuze, Frankfurt/M 1980. O pojęciu masochizmu pisze także G. Ritz, Grenzen und Perspektiven der GenderStudies (w druku). 
ciała ksztaltuje „schizofreniczne” podejście do rozpadu „porządku Ojca” (z jego prymatem ducha nad ciałem, męskości nad kobiecością). Polega ono na - wynikającej z poczucia dramatycznej straty - potrzebie nostalgicznej rekonstrukcji tego patriarchalnego porządku z jednej, a jego dekonstrukcji z drugiej strony.

Semantyczne centrum tej prozy stanowi poczucie wyobcowania między ojcem a synem, których związek ma w kulturze żydowskiej charakter szczególnie intymny ${ }^{6}$. Podmiot bezskutecznie stara się wyobcowanie to przezwyciężyć poprzez mityczno-patetyczne uwznioślenie ojca, a także wykoncypowanie figur ojca i syna jako upodobnionych do siebie i wskazujących na samego autora. Sakralizacja ojca jest jednak podminowana degradacją. Wysiłki syna, by rozpoznać siebie jako „spadkobiercę” w powstałej próżni sensu (Sinnvakuum ${ }^{7}$ ), i to poprzez podwójny, regresywny i progresywny ruch (w kierunku wyimaginowanych korzeni i utopijnych celów), są ustawicznie i groteskowo unicestwiane przez narratora.

Dzięki jakim procedurom zagrożony „porządek ojca” zostaje uwznioślony, a stosunek do ojca umocniony? Przykład Schulza jest jakby ilustracją znanej tezy Theleweita ${ }^{8}$ na temat fantazmatów męskiego „samorództwa". W pierwszym rozdziale Sanatorium pod klepsydra, zatytułowanym Księga, narrator wyobraża sobie dziecięcą arkadię nie na piersiach matki, lecz w gabinecie ojca, heretycko tym samym podważając podstawowy dogmat psychoanalizy o pierwotności symbiozy matka-dziecko. Bohater Schulza wyznaje: „To było bardzo dawno. Matki jeszcze wówczas nie było. Spędzałem dni sam na sam z ojcem w naszym, wielkim wówczas jak świat, pokoju". ${ }^{9}$ Preedypalna symbioza $z$ matką została przemilczana, a kobiece ciało, jako miejsce własnego początku, zanegowane. Taka postawa nie jest, zdaniem feministycznej filozofki Lucy Irigary, niczym nadzwyczajnym, zważywszy że męskość konstruowana jest w zachodniej myśli filozoficznej jako ,jedność” i „początek” właśnie - koncepcja ta konkuruje $\mathrm{z}$ kobiecą, biologiczną siłą reprodukcji ${ }^{10}$.

${ }^{6}$ Według Mitscherlicha jest to charakterystyczne dla zachodniej kultury epoki industrialnej, por. A. Mitscherlich, Auf dem Weg zur vaterlosen Gesellschaft. Ideen zur Sozialpsychologie, Weinheim 2003.

7 Pojecia „Sinnvakuum“ (próżnia sensu) używam w oparciu o teorie psychologiczne Viktora Frankla; por. V. Frank1, Arztliche Seelsorge. Grundlagen der Logotherapie und Existenzanalyse, Frankfurt/M 1998.

${ }^{8}$ Por. K. Theleweit, Männerphantasien, t. II, Frankfurt/M 1977.

${ }^{9} \mathrm{~B}$. Schulz, Wybór esejów i listów, red. J. Jarzębski, Wrocław 1989, s. 106. Wszystkie cytaty z Schulza pochodzą z tego wydania.

10 Por. L. Lindhoff, Einführung in die feministische Literaturwissenschaft, Stuttgart 1995. 
Biblioteka ojca, miejsce pieczołowicie chronionej tradycji, przedstawiona jest jako centrum krystalizacji sensu ${ }^{11}$. Pod tym względem tekst Schulza reprodukuje skrypt naszej kultury. Na biurku leży magiczna, wspaniała Księga, uosobienie mistycznej jedności słowa i rzeczy, ducha i materii. Jej prototypem jest być może jedna $\mathrm{z}$ ksiąg handlowych Jakuba celebrującego swój interes jak czynność sakralną. Spotkanie z Księgą umożliwia synowi Józefowi12 - jak to sobie melancholijnie przypomina dorosły już pierwszoosobowy narrator - poczucie związku z nieskończonym Kosmosem. Stylizowana jest na pierwotne źródło inspiracji (początek) i wspominana $\mathrm{z}$ wielką żywioną ku ojcu czułością. Poruszona wilgotnym palcem czytającego ojca, jakby dotknięta jakąś czarodziejską różdżką (symbol fallusa), Księga zaczyna mienić się w oczach chłopca i stawać całym światem, ponieważ ów świat objaśnia w sposób spójny i przekonujący ${ }^{13}$. Tak jak Księga rozpala wyobraźnię chłopca, tak cielesna bliskość ojca dostarcza mu poczucia bezpieczeństwa i pewności. Źródło rojeń na temat swojego „początku” lokuje narrator, paradoksalnie, między nogami ojca (!): „Stałem między nogami ojca...”. Obrazem tym nader wyraziście sięga Schulz po fantazmaty patriarchatu dręczonego zazdrością o kobiecą zdolność rodzenia - po fantazmaty samorództwa, narodzin bez udziału matki14, podważające ekskluzywne prawo kobiet do dawania życia. W obrębie tego fantazmatu męski podmiot stylizowany jest na wyłącznego producenta i władcę świata.

Ojcowskie nogi znacząco metaforyzowane są jako kolumny: „Lubiłem stawać między nogami ojca, obejmując je z obu stron, jak kolumny”. ${ }^{15}$ Kojąca styczność z ojcowskim ciałem jest więc dotknięciem kamienia. Kolumny mogą - poprzez asocjacje z antykiem - uchodzić za symbol zachodniej kultury. Odwołując się do kategorii Irigary ${ }^{16}$ i Deleuze'a17 można również stwierdzić, że metafora kolumn wskazuje na tendencję kultury judeo-chrześcijańskiej do negowania, opatrywania zakazem i zamykania $w$ sztywne formy ( $w$ sztuce są to często statuy czy lalki) wszystkiego, co cielesne, żywe i zmysłowe (kojarzone z kobiecością). Nogi jako kolumny symbolizują jednak również mocną, niewzruszoną (jeszcze) pozycję wszechmocnego Ojca.

\footnotetext{
11 Por.W. Erhart, B. Hermann, Wann ist..., op. cit., s. 51.

12 Należy zwrócić uwagę na biblijne imię.

${ }^{13}$ Nie tylko ojcowski sposób czytania, także i pismo ojca (listy handlowe) ujmuje chłopca swą wyszukaną formą estetyczną (,zakrętasy podpisu”).

14 Por. mity o narodzinach Ateny i Dionizosa.

15 B. Schulz, Wybór esejów..., op. cit., s. 106.

${ }_{16}$ L. Irigaray, Speculum. Der Spiegel des anderen Geschlechts, Frankfurt/M 1980,
} s. 119.

17 Por. G. Deleuze, Sacher Masoch..., op. cit. 
Przywoływany wspomnieniem ojcowski świat, ów patriarchalny „porządek Ojca", pokazany jest jako świat kulturotwórczej kreatywności i włączania nadprzyrodzonego w sferę codzienności, przeniesienia wypieranej zmysłowości w sferę mistycznej kontemplacji. To nie jest tylko świat prawa i logosu, ale także, a może przede wszystkim, świat mitu i rytuału. Ojciec (który zarazem oznacza Boga-ojca) jest magiem i czarodziejem, i - w przeciwieństwie do kobiecych postaci Schulza, działających $w$ horyzontalnej przestrzeni codzienności i osadzonych w materialności - reprezentuje wertykalne zakotwiczenie bytu w micie, czerpanie z praźródeł, z pierwotnego sensu i cudowności18. Ojciec reprezentuje nie tyle Logos, lecz przede wszystkim mit, co jest uzasadnione specyfiką tradycyjnego podziału ról w społeczeństwie żydowskim ${ }^{19}$.

Wtargnięcie matki $\mathrm{w}$ ten nienaruszony świat jest równoznaczne $\mathrm{z}$ upadkiem $\mathrm{i}$ wygnaniem $\mathrm{z}$ raju. Matka niczym biblijna Ewa wydziera chłopca ojcu - jak to widziane jest z perspektywy narratora - oddala od praźródła jego pełni życia: „Potem przyszła matka i wczesna ta, jasna idylla skończyła się. Uwiedziony pieszczotami matki, zapomniałem o ojcu, życie moje potoczyło się nowym, odmiennym torem, bez świąt $\mathrm{i}$ bez cudów [...]"20. Winę za owo odejście ponosi jednak nie tylko uwodzicielska matka, ale przede wszystkim sam ojciec. Już w pierwszym zdaniu Sklepów cynamonowych sugeruje się jego zdradę21. Jakub jedzie do sanatorium i zostawia syna „na pastwę" nieobliczalnej kobiecości, która wedle zachodnich wyobrażeń utożsamiania jest z cielesnością, biologią i chaosem. W oczach narratora ojciec winny jest także dalszych zdrad. Zgubił bowiem Księgę, będącą gwarantem ojcowskiego porządku świata i sensu. W rozdziale Ksiega (Sanatorium pod klepsydra) mały Józef wpada do biblioteki ojca i nie znajduje już płomiennej, natchnionej Księgi (Oryginału). To, co zrezygnowany ojciec daje mu do ręki, odbiera jako falsyfikat. To Biblia, postrzegana tutaj jako symbol zastygłej religijności, pozbawionej żywego, celebrowanego mitu (por. J. Campbell) - świadectwo

18 Por. J. Asmann, Zitathaftes Leben. Thomas Mann und die Phänomenologie der kulturellen Erinnerung, „Thomas Mann Jahrbuch“ 6 (1993), 148 i następne.

19 Żydowski ojciec nie jest odpowiedzialny - jak to jest w tradycji chrześcijańskiej za utrzymanie rodziny i dlatego nie kieruje się ku zdobywaniu zewnętrznego świata, lecz zwraca się ku studiowaniu świętych ksiąg, pielęgnuje kontakty z bóstwem. Nawet jeśli warunki ekonomiczne temu nie sprzyjają, pozostaje (zwłaszcza w wyobraźni syna) kapłanem i profetą. Por. B. Umińska, Specyfika żdowskiego patriarchatu, w: Postać z cieniem. Portrety Żydówek $w$ polskiej literaturze, Warszawa 2001, s. 47-64.

20 B. Schulz, Wybór esejów..., op. cit., s. 107.

21 Zdaniem wielu psychoanalityków w dojrzewającym chłopcu rodzi się szczególna potrzeba bliskiego kontaktu z ojcem, który „zapewnia mu ochronę przed pożerającym fantomem preedypalnej matki". Por. W. Erhart, B. Hermann, Wann ist..., s. 54. 
utraty sensu i mocy przez ojca ${ }^{22}$. „Prawdziwa” Księga ulega w ten sposób demaskacji jako fantazja syna, znikająca wraz $\mathrm{z}$ końcem dzieciństwa czyli życia rozpiętego między realnością i imaginacją; wraz z wejściem $\mathrm{w}$ dorosłe życie i jego symboliczny porządek. W jednej z konfrontacyjnych rozmów z synem ojciec zaprzecza istnieniu Księgi i sugeruje, że była tylko dziecięcym wymysłem Józefa: „Księga jest mitem, w który wierzymy w młodości, ale z biegiem lat przestaje się ją traktować poważnie"23. To moment dramatycznej deziluzji bohatera - jasne staje się, że nie istnieją uniwersalne mity i interpretacyjne modele, pozwalające objaśnić świat raz na zawsze, a ojciec nie jest prorokiem. Podobne rozpoznanie wstrząsnęło europejską moderną.

Wygnaniu z ojcowskiego raju w okresie wczesnego dzieciństwa towarzyszy tragiczne rozpoznanie, że tak naprawdę raj ten nigdy nie istniał, oraz cierpienie spowodowane niemożliwością inicjacji w „świat Ojca”. Między ojca i syna zostaje wbity klin, ponieważ syn wzbrania się przed akceptacją owej deziluzji: „Miałem już wówczas inne przekonanie, wiedziałem, że Księga jest postulatem, że jest zadaniem. Czułem na barkach ciężar wielkiego posłannictwa. Nie odpowiedziałem nic, pełen pogardy [...]"24. Wkracza tu do opowiadania Schulza „dyskurs zbawienia”, ściśle związany z jego koncepcją sztuki, o której pisał m.in. w swojej korespondencji. Józef zaczyna pogardzać wykastrowanym ojcem, ojcem pozbawionym czarodziejskiej różdżki i przyjmuje na siebie - nawiązując do romantycznego rozumienia artysty - misję restytucji Księgi. Projekt ten narrator łączy z kabalistycznymi wyobrażeniami zbawienia, $\mathrm{z}$ mitami traktującymi o zgubnym pęknięciu pranaczyń w procesie kosmogonicznym, co stało się przyczyną rozbicia świata na sprzeczności i antagonizmy. Odbudowanie pierwotnej całości jest zadaniem Mesjasza, ale każdy człowiek - jak już twierdził kabalista Izaak Luria - może przyspieszyć zbawienie dzięki własnym staraniom ${ }^{25}$. Medium owego zbawienia czyni Schulz - zarówno w listach, jak i w prozie - sztukę, zdolną przywrócić do życia magiczne, typowe dla okresu dzieciństwa odczuwanie przestrzeni i czasu ${ }^{26}$. Jednocześnie mamy jednak do czynienia z ironicznym podminowaniem owej „świadomości posłannictwa”. Strzępy utraconej Księgi rozpoznaje Józef, absurdalnie, w reklamach brukowych gazet $\mathrm{i}$ albumie ze znaczkami swego przyjaciela Rudolfa. Swiat składa

${ }^{22}$ Por. K. Hübner, Höllenfahrt. Versuch einer Deutung von Thomas Manns Vorspiel zu seinen „Josephs-Romanen”, „Thomas Mann Jahrbuch” 6 (1993), s. 86.

${ }^{23}$ B. Schulz, Wybór esejów..., op. cit., s. 108.

24 Tamże, s. 108.

${ }_{25}$ Por. W. Panas, Księga blasku. Traktat o kabale $w$ prozie Bruno Schulza, Lublin 1997.

${ }^{26}$ Por. np. list Schulza do Witkacego, w: B. Schulz, Proza, Kraków 1964, s. 682. 
się więc $\mathrm{z}$ fragmentów, jest rozkawałkowany, Księgę można zrekonstruować teraz już tylko jako karykaturę samej siebie.

Nie oznacza to jednak, że Józef, tekstowy ślad samego autora, rezygnuje ze swych tęsknot i usiłowań. Możliwość „ratunku” odnajduje w posłannictwie artysty. Inicjacja Józefa w sztukę rysunku dokonuje się w odniesieniu do dziecięcych fantazji o wszechmocnym ojcu. Chłopiec rysuje na stronach wyrwanych $\mathrm{z}$ ksiąg handlowych ojca (tworzy swoisty „palimpsest”), pisze na ojcowskim piśmie, zajmuje tym samym miejsce ojca i przejmuje jego dziedzictwo ${ }^{27}$. Nie dziwi więc, że artystą stać się może jedynie poprzez radykalne oddzielenie się od erotycznego, zaborczego ciała matki: „Moja matka przybiegła przerażona i objęła mój krzyk ramionami, chcąc go nakryć jak pożar i stłumić w fałdach swojej miłości. Zamknęła mi usta ustami i krzyczała razem ze mną"28. Syn odrzuca matkę, która jest cała cielesnością, i dopiero wtedy doświadcza ekstazy, eksplozji dotychczas „zamurowanego sensu” - w nawiązującej do Biblii wizji płonącej kolumny o fallicznym kształcie. Proces twórczy umożliwia mu kontakt $\mathrm{z}$ archaicznymi archetypami męskości. Jego sztuka jest z jednej strony twórcza i ocalająca (analogiczna do stworzenia świata i budowy Arki Noego), z drugiej okrutna, mordercza, zabijająca: „Było to rysowanie pełne okrucieństwa, zasadzek i napaści. Gdy tak siedziałem napięty jak łuk [...], a w słońcu dookoła mnie płonęły jaskrawo papiery - wystarczyło, aby rysunek, przygwożdżony mym ołówkiem, uczynił najlżejszy ruch do ucieczki. Wówczas ręka moja [...] rzucała się nań z wściekłością jak kot i już obca, zdziczała, drapieżna [...]. I dopiero wtedy odluźniała się od papieru, gdy martwe już i nieruchome zwłoki rozkładały $\mid$... $\mid$ swą fantastyczną i kolorową anatomię na zeszycie"29. To karykatura władczego, mortyfikującego, nastawionego na kontrolę i pacyfikację traktowania „nieobliczalnej” cielesności i natury przez kulturę zachodnią, obraz zakuwania w formy tego, co zmysłowe i cielesne (Deleuze). Syn nazbyt gorliwie wypełnia „prawo ojca” - w ten sposób w tekst wkracza groteska, dekonstrukcja przekazu „ojcowskiego".

Artystyczna działalność chłopca odsyła do twórczości samego Schulza. Podobny los, jaki spotyka zwierzęta z rysunków Józefa, jest udziałem

27 Analogicznie do tego Schulz pisze, jak zauważyła Renate Lachmann, jakby na podkładach literatury biblijnej, kabalistycznej, gnostyckiej i psychoanalitycznej oraz dzieł literackich, powstałych z inspiracji jego „ojców” duchowych (można tu wymienić np. Przemian̨̨ Kafki czy powieści o Józefie Thomasa Manna). Por. R. Lachmann, Dezentrierte Bilder. Die ekstatische Imagination in Bruno Schulz, Prosa, Psychopoetik, „Wiener Slawistischer Almanach“, Sonderband 31, red. A. Hansena-Löve, Wien 1992, s. 439-461.

28 Stwarzanie dziel sztuki czyni Józefa odpornym na uwiedzenie przez kobietę (dotyczy to również Adeli).

${ }^{29}$ B. Schulz, Wybór esejów..., op. cit., s. 124. 
kobiecych postaci na Schulzowskich grafikach. Są one wprawdzie niekiedy wyposażone w bicze, ale na ogół pozbawione witalności. Podmiotowość jest im jakby tylko chwilowo użyczona zawsze zachowującym dystans spojrzeniem męskiego masochisty (który niejednokrotnie nosi rysy samego artysty). Kobiety na grafikach Schulza adorowane są tylko w takiej poskramiającej i poskromionej, zastygłej, ciągle tej samej, niedostępnej formie, wykluczającej wszelką intymność; są jak lalki, trupy, zabalsamowane ciała (a zatem „dyspozycyjne” i nieszkodliwe przedmioty). Także to można wytłumaczyć teorią masochizmu Deleuzea. Wedle niej podległa tabu cielesność w kulturze zachodniej często przesunięta zostaje na społecznie akceptowaną pozycję pozbawionego zmysłowości artystycznego obiektu, np. zimnej statuy, która staje się przedmiotem mistycznego uwielbienia, jak w Wenus $w$ futrze Sachera Masocha ${ }^{30}$. W ten sposób hierarchia płci zostaje pozornie przekręcona, stosunki sił odwrócone, prawo oddane w ręce "matki”, a „ojciec” unieważniony. A jednak twórcą tego układu ciągle jeszcze jest podmiot męski, który chwilowo przydziela sobie rolę obiektu oraz - parodiując prawo ojca - sam siebie karze za własne pożądanie. Także i to przystaje do malarskich prac Schulza.

Masochizm i fetyszyzm są również ważnymi tematami jego prozy, związanymi z postacią upokorzonego, zdetronizowanego ojca. Centrum nielinearnej narracji Schulza, splątanej i stylistycznie niejako „występującej z brzegów", jest pozbawienie ojca władzy i autorytetu przez służąca Adelę i upadek jego domu (zauważmy, że powieściowy ojciec nosi imię ojca pisarza). To właśnie u Adeli, której oddaje rolę podmiotu, ojciec - upadły patriarcha - lokalizuje fallus ${ }^{31}$. Widok tej wymachującej miotłą figury Lilith i femme fatale wprawia starego Jakuba w erotyczne podniecenie, co trywializuje go w oczach czytelnika. Inne substytuty fallusa (fetysze), jak np. palec Adeli wyciągnięty do łaskotek, czy jej noga kusząca jak język węża, służą cenzurowaniu demiurgicznych fantazji ojca, zmuszają go, by padł na kolana i stał się niewolnikiem własnej żądzy. Także tutaj masochizm staje się medium pozornego wywrócenia hierarchii płci i metonimiczno-metaforycznej inscenizacji kryzysu męskości. Trudno brać na serio subwersywną, dekonstrukcyjną energię tego motywu, ponieważ pożądanie masochisty nakierowane jest na mocno skonwencjonalizowaną formę reprezentacji kobiety, której potencjał zastyga $\mathrm{w}$ spacyfikowanej formie fetyszu.

Cała twórczość literacka Schulza oscyluje między fobiami kobiecości i kastracyjnymi lękami z jednej, a denuncjacją patriarchatu $z$ drugiej strony. Charakterystyczne dla okresu międzywojennego obsesje mitów

${ }^{30}$ G. Deleuze, Sacher Masoch..., op. cit., s. 207.

31 Freud definiuje masochizm i fetyszyzm jako wyraz lęku przed kastracją i projekcję fallusa na kobietę. 
kobiecości i fascynacje matriarchatem, manifestowane np. w Demianie Hessego $^{32}$, podejmuje również Schulz, wpisując w swój tekst także związane z tym przerażenie. Fobie kobiecości pojawiają się już w pierwszym rozdziale Sklepów cynamonowych (zatytułowanym Sierpień) w makabrycznej postaci Tłuji. W pewnym oddalonym od cywilizacji miejscu (na hałdzie śmieci) porzucony przez ojca Józef napotyka „pogańską” orgię wariatki z pniem drzewa. Kobiecość zepchnięta przez proces cywilizacyjny na margines kultury, czy nawet wyrugowana $\mathrm{z}$ jej przestrzeni ${ }^{33}$, powraca tutaj jako upiór - jest to znane w kulturze zachodniej zobrazowanie patriarchalnych lęków przed odwetem kobiet. Sporo miejsca przeznacza narrator przerażającym wizjom tej rozprzężonej, groźnej kobiecości, wymykającej się kształtującej sile męskiego spojrzenia, kobiecości, której skandaliczną pożądliwość da się wytłumaczyć tylko chorobą psychiczną.

Pomiędzy fetyszystycznym, sztucznym ciałem Adeli i niecywilizowanym, bez-kulturowym ciałem Tłuji znajduje się postać ciotki Agaty. Jej cielesność i zmysłowość zostają pokazane w kontekście macierzyństwa. Narrator insynuuje jej „płodność niechlujną i nieumiarkowaną”, „szał rodzenia" 34 , który może obyć się bez męskiego udziału. U boku despotycznej ciotki (pramatki) autor stawia złamanego małżonka, który nie potrafi bronić się przed „zalewającą rzeką kobiecości”. W tym samym rozdziale mały Józef, pozbawiony ojca, osaczony kobietami, wciągnięty (wtajemniczony) zostaje w krąg seksualnie sparaliżowanych męskich postaci. Pozbawiony wyrazu kuzyn podczas pokazywania Józefowi pism pornograficznych bierze go między kolana i daje mu odczuć swój pobudzony członek, niezdolny wszakże do erekcji ${ }^{35}$ - także ten obraz wiele mówi o kryzysie męskiego podmiotu.

Władza fallusa (który działać może już tylko tak „nielegalnie”) jest w obydwu tomach prozatorskich ostatecznie przełamana. Prymat ducha nad ciałem, oczywistość ojcowskiego, patriarchalnego, a także politycznogospodarczego porządku oraz tradycji żydowskiej tracą swój fundament. W przejmujących obrazach narrator pokazuje, jak świat zaczyna wymykać się spod kontroli ojca: dom jest zaniedbany, zagraża mu pogrążenie $\mathrm{w}$ chaosie, co m.in. symbolizują wszędzie wciskające się karaluchy. W obliczu tej przewidywanej katastrofy ojciec zostaje tragikomicznie uwznioślony do postaci biblijnego Jakuba i Mojżesza, staje się prorokiem

32 Por. F.A. Lubich, Bachofens „Mutterrecht", Hesses „Demian“ und der Verfall der Vatermacht, „The German Review 65 (1980), s. 150-158.

33 M. Horckheimer, Th. Adorno, Dialektik der Aufklärung, Frankfurt/M 1969.

34 B. Schulz, Wybór esejów..., op. cit., s. 11.

35 Po tym zdarzeniu jego twarz rozplywa się znowu w nicości. Por. A. Sandauer, Rzeczywistość zdegradowana, op. cit. 
i męczennikiem, ostatnim bastionem broniącym dostępu nowoczesnemu upadkowi obyczajności oraz blazeńskiej beztrosce kupców i desakralizacji handlu. Sklep (który jednocześnie symbolizuje zagrożoną kulturę) jawi się wrażliwemu narratorowi jako zadanie, które przerosło siły Jakuba, pod którego ciężarem się załamał. Ojciec wprawdzie podtrzymuje resztkami sił - jak mityczny Atlas - rozsypujący się świat, traci jednak związek z nadającą sens transcendencją (ośmieszone zostają jego dialogi z Bogiem) i przez to decydujący współczynnik sukcesu. Do metafory rozpadającego się świata należą także obrazy biologicznej inwazji: dziczejący sklep biorą w posiadanie chwasty, śmieci i pajęczyny oraz zwyrodniałe, wymierające muchy. Także ojciec przeobraża się $w$ nieznośnie biadolącą, monstrualną muchę (jedną $\mathrm{z}$ ostatnich $\mathrm{z}$ „rodu”) - to jeden $\mathrm{z}$ wielu przykładów polimorficznego szaleństwa autora, który może być odczytany jako próba nawiązania do Przemiany Kafki, a nawet jej przewyższenia ${ }^{36}$. Najwyższym jednak punktem metamorfozy jest przemiana ojca w karalucha, co ostatecznie pozbawia go sympatii rodziny i ma w sobie wielką symboliczną siłę wyrazu.

Zanim to jednak nastąpi narrator pozwoli ojcu, w rozdziale Ptaki (w Sklepach cynamonowych), walczyć o własną godność środkami okupacji kobiecej zdolności rodzenia. Najpierw Jakub hoduje w domu barwne, egzotyczne ptaki. Nie bacząc na groteskowy zwrot przedsięwzięcia w sferę fekalną, narrator przedstawia te działania jako „odświeżający wybuch poezji”, karkołomnie oscylując między denuncjacją i heroizacją ojca. Tryumf uzurpatora kończy się symboliczną kastracją: śmierdzące ptasie królestwo zostaje brutalnie wymiecione przez Adelę. W tym przypadku rola podmiotu nie zostaje Adeli „przydzielona” w masochistycznym ukladzie, tutaj Adela faktycznie staje się działającym podmiotem, udzielającym sobie władzy. Nie oznacza to oderwania się od patriarchalnych klisz kobiecości - nasuwa się tu chociażby porównanie do mitologicznych narracji o Dalidzie i Judycie, które doprowadziły męskich bohaterów do upadku - jednakże klisze te nie są u Schulza reprodukowane jednoznacznie. Przez fakt, że ojciec jest nie tyle „bohaterem”, ile karykaturą bohatera, te obiegowe sądy na temat kobiecości tracą wiarygodność, a nawet doprowadzone zostaja ad absurdum.

Epizodycznie ironizowana i poddana subwersji jest także obowiązująca hierarchizacja duszy i ciała. W Traktacie o manekinach (Sklepy cynamonowe) ojcu przypada rola „nielegalnego, heretyckiego demiurga” i inteligentnego (uduchowionego) wielbiciela materii. Parodiuje tu Schulz motywy wtórnego stworzenia, jakie pojawiają się m.in. w gnozie, micie

${ }^{36}$ Już w poprzednim rozdziale autor „kazał” ojcu wspinać się na szafy i karnisze, piać trzepocząc ramionami i gorliwie naśladować wypchanego kondora. 
Pigmaliona czy literaturze niemieckiego romantyzmu ${ }^{37}$. Dzieje się tak w pseudofilozoficznych tyradach ojca, wygłaszanych przed dwoma szwaczkami i Adelą. Są one osadzone w ramach akcji dyskredytującej piękne retoryczne spekulacje wielkiego "mędrca” jako zamaskowaną seksualną fantazje "starego lubieżnika” i czyniącej z nich parodię filozoficznego dyskursu myśli zachodniej. Ojciec, studiując „naukowo” mechanikę odzianych $w$ pończochy łydek szwaczek, popada w groteskową rywalizację z Bogiem, w projekt bluźnierczej antropogonii, wtórnego stworzenia człowieka. W ten sposób Schulz hiperbolizuje wielkie narracje naszej kultury, wyciąga $z$ nich ostateczne konsekwencje i pokazuje ich „cień" przede wszystkim pozbawienie wartości ciała, zwłaszcza kobiecego, i uczynienie z niego obiektu: „Słowem - konkludował mój ojciec - chcemy stworzyć po raz wtóry człowieka, na obraz i podobieństwo manekina"38. Kilkakrotnie skarcony przez Adelę ojciec zmienia jednak kurs, niejako odwraca włócznię i nazywa tego rodzaju formowanie materii przemocą, ukrzyżowaniem i bezprawiem. Oznajmia, że pozwoli dzikiej materii wedrzeć się do opuszczonych pokojów i rozwijać efemeryczne kwiaty. W ten sposób także na poziomie postaci bluźnierczo podważony zostaje dogmat wyższości ducha nad materią39.

Podczas gdy podniecony seksualnie ojciec rozkoszuje się fantazjami o manekinach, także i autor (który wobec ojca zajmuje pozycję sobowtórową) upaja się pisarskim produkowaniem manekinów. Obydwie szwaczki metaforyzowane są bowiem jako lalki, co przekonująco dowiódł Frei$\mathrm{se}^{40}$. To karykatury oswojonej, udomowionej i uprzedmiotowionej kobiecości. Szwaczki są jednak tylko kopiami prawdziwego „potwornego i nieustępliwego bożyszcza” - olbrzymiego krawieckiego manekina, będącego zarazem modelem i bożkiem, któremu oddają hołd ${ }^{41}$. Dla narratora manekin ten jest uosobieniem pozbawionej ducha, zakochanej w sobie kobiecości, „nieprzebłaganym molochem, jakim tylko kobiece molochy być potrafią". Obraz ten można zestawić z powszechnie znanym rozpoznaniem psychoanalitycznym, że to, co zepchnięte i poddane tabuizacji

${ }^{37}$ Por. Pygmalion. Die Geschichte des Mythos in der abendländischen Kultur, red. M. Meyer, G. Neumann, Freiburg 1987.

${ }^{38}$ B. Schulz, Wybór esejów..., op. cit., s. 36.

${ }^{39} \mathrm{Na}$ poziomie autorskim można ten fragment interpretować jako częściowo afirmatywne, częściowo parodiujące nawiązanie do Leśmianowskiego obrazu świata. Por. B. Helbig-Mischewski, Die Worte treiben Unzucht im Himmel. Bolestaw Leśmian und die Subjektauffassungen der Spätmoderne, w: Lyrik der Spätmoderne in Ost-MittelEuropa, red. A. Kliems, U. Raßloff, P. Zajac, Stuttgart 2006.

40 Por. M. Freise, Das Motiv..., op. cit.

41 Dziewczyny wnoszą manekina do gabinetu na rękach. Obraz ten można interpretować jako wyraz uwielbienia i zamiaru pogrzebania, gloryfikacji i mortyfikacji. 
(ciało) staje się przedmiotem tajemnej czci. Cielesne i żywe także i tu zostaje przekształcone w to, co sztuczne i oddane do dyspozycji jako obiekt (masochistycznej adoracji).

Także Adela jest przez narratora stylizowana na manekina - na co zwróciła już uwagę Umińska42 - śpiąca, naga i bezradna daje się brać w posiadanie sprzedawcom, poddaje się spojrzeniu ojca czy czołgającego się pod jej oknem kalekiego Edzia. Wobec przemocy męskiego spojrzenia kobiece postacie są bezradne, nawet jeśli uzyskują tymczasowy status podmiotowości. Marionetkowość Adeli szczególnie uwidoczniona jest w scenie z Edziem pozbawionym nóg ${ }^{43}$. Cały ród pluskiew (które mogą symbolizować społeczeństwo patriarchalne) wysyła narrator w podróż przez ciało służącej, które nie czuje „żadnego poruszenia”. W ten sposób śpiąca kobieta zostaje unieruchomiona i zgwałcona ${ }^{44}$. „Olbrzymia pluskwa”, która jako ostatnia przechodzi przez ciało Adeli, może symbolizować fallus. Może być także, jeśli pozwolimy sobie na skojarzenia z Przemianq Kafki, aluzją do Gregora Samsy, którego zwłoki usunięte zostały przez służącą (!). Zauważmy, że przez ciało Adeli wędrują pluskwy, nie zaś kochające i pożądające dłonie. Bezpośredni kontakt ciał jest bowiem w ramach masochistycznego układu objęty zakazem. Zaprezentowany tu rodzaj kontaktu jest właśnie masochistyczny, oparty na dystansie wobec ciała (Edzia oddziela od Adeli szyba okienna). W ten sposób dotknięcie kobiecego ciała zostaje odsunięte od męskiego podmiotu; dokonuje się w atmosferze „odrazy”, co charakterystyczne jest dla kultury, oddzielającej sferę seksualną od spirytualnej i spychającej tę pierwszą w obszar obsceniczności.

Scenę z Edziem można - ze względu na jej makabryczną fantastykę - interpretować jako ironiczną i demaskatorską. Ten rodzaj interpretacji znajduje legitymizację w podkreślaniu przez narratora „realnej” witalności i przewagi postaci kobiecych, które ratują dotknięty kryzysem świat przed zagładą. Bez kobiecego wsparcia mężczyźni Schulza nie nadają się do życia. Gdy żona „pana Karola” (tytułowego bohatera jednego z rozdziałów Sklepów cynamonowych) wyjeżdża na wakacje, nie jest on w stanie oprzeć się pokusie bezustannego spania i seksualnych ekscesów. Zaś w opowiadaniu Dodo (Sanatorium pod Klepsydra) to kobieta pośredniczy między ojcem, ględzącym bez sensu prorokiem w szlafroku, i jego umysłowo upośledzonym synem Dodo. W obliczu ptasiej apokalipsy w ostatnim opowiadaniu z cyklu Sklepy cynamonowe to pierś Adeli daje na-

42 B. Umińska, Postać z cieniem. Portrety..., op. cit.

43 Edzio należy do grona męskich „impotentów” (nieudolnych, chorych, kalekich, infantylnych), którzy zapełniają twórczość literacką i graficzną Schulza.

44 Podobnie jak we współczesnym kultowym filmie P. Almodovara Porozmawiaj z nia (2002). Por. też motyw „martwej narzeczonej” w sztuce zachodnioeuropejskiej. 
dzieję na nowy początek: „Adela, ciepła od snu i ze zmierzwionymi włosami, mełła kawę na młynku, przyciskając go do białej piersi, od której ziarna nabierały blasku i gorąca"45.

W to, że koniec świata jest bliski, narrator nie pozwala wątpić niko$\mathrm{mu}^{46}$. Rozpad starej kultury i „porządku ojcowskiego” symbolizują - obok „wybrakowanych" męskich postaci - rozpadające się gipsowe rzeźby bogów greckich, stojące w szkolnej sali do rysunków (opowiadanie tytułowe w Sklepach cynamonowych) oraz przedstawieni z czułością brodaci, majestatyczni ex-patriarchowie żydowscy, błąkający się w świecie wyobraźni narratora jako zabiedzeni pielgrzymi lub kataryniarze: „[...] lubię ich głęboką powagę, ich funebryczną dekoratywność, te wspaniałe okazy męskie [...], lubię ten szlachetny brak żywotności w ciałach wybujałych i gąbczastych, morbidezzę wygasających rodów"47. Do tego kontekstu należy także groteskowa parada dwunastu figur woskowych w Wiośnie (Sanatorium pod klepsydrq $)^{48}$, przy których pomocy Józef bezskutecznie próbuje zbawić świat. Ostatecznie jednak narratorowi nie udaje się ani ojca, ani siebie samego wpisać bez zakłóceń w strukturę mityczną. Rzeczywistość i mit przestały być kompatybilne, praobrazy nie dają się już odróżnić od ułudy. Także i to rozpoznanie można by wpisać w paradygmat awangardy, gdyby nie te rozpaczne próby reanimacji mitu i obecność sprzecznych wewnętrznie tendencji.

Zdyskredytowane patriarchalne ideały męskości i mity kultury zachodniej, które autor równocześnie re- i dekonstruuje, zostają skontrastowane $\mathrm{z}$ archaicznym matriarchatem, zapewne zaczerpniętym $\mathrm{z}$ książki Bachofena49. Jak już wcześniej pisałam, kobiecość u Schulza rozdzielona została na trzy kategorie: erotycznej reprezentacji (Adela), obłędu (Tłuja) i macierzyństwa (Agata). Do macierzyńskiego paradygmatu zaliczyć można także postać niani. W rozdziale Noc lipcowa (Sanatorium pod klepsydrq) narrator czuje, że od momentu narodzin siostrzeńca konfrontowany jest $\mathrm{z}$ „prymitywną gynokracją", którą reprezentuje ekspansywna, „obfita cielesność" i „lubieżna płodność” niańki (Wielkiej Matki). Stosunek Józefa do tej nowej formy współżycia socjalnego oscyluje między głębokim przerażeniem i równie głębokim zachwytem. Wróciwszy z nocnej odysei po burdelach, Józef zastaje szwagra walczącego

${ }^{45}$ B. Schulz, Noc wielkiego sezonu, w: tegoż, Proza, Kraków 1973, s. 120.

${ }^{46}$ Schulz bez wątpienia znał książkę Untergang des Abendlandes Oswalda Spenglera, która ukazała się w dwu tomach w 1918 i 1922.

${ }^{47}$ B. Schulz, Wybór esejów..., op. cit., s. 104.

48 Jest to parodia dwunastu uczniów Jezusa. Por. W. Kośny , „Bo czymże jest wiosna jeśli nie zmartwychwstaniem historii?“ Zu Bruno Schulz’ Erzählung „Wiosna”, „Zeitschrift für Slavische Philologie“ Bd. 55, 1995/96, H. 2, s. 313-322.

49 Por. J.J. Bach ofen, Das Mutterrecht (1861). 
we śnie ze strasznym brzemieniem, ojca ssącego piersi snu (nie żony!), wszystkich członków rodziny zredukowanych do wegetatywnych funkcji, animałnych, martwych: „cielska [...] leżały zabite jak czarne bezwładne bydlęta $\mathrm{z}$ wywalonymi ozorami, lejąc ślinę $\mathrm{z}$ bezsilnych pysków”50. Także w tym fragmencie kryją się obawy przed odwróceniem dotychczasowych hierarchii wartości.

Aby zagłuszyć ową „matriarchalną” grozę w następnym rozdziale narrator serwuje czytelnikowi kolejną wojskową paradę - ojciec święci tryumfy jako przywódca zuniformizowanych strażaków. Ten heroiczny wariant ojca jest wszakże tylko życzeniową fantazją małego chłopca. Ojciec buntuje się tu jeden jedyny raz kierując płomienną tyradę w stronę Adeli, i wzbudzając tym samym podziw własnej żony. Powiększony przez potężną rycerską zbroję podkrada sok malinowy Adeli i daje swojej drużynie, by „(...) podnieść z upadku to plemię, wyprowadzić je z poniżenia i rozpiąć nad nim sztandar nowej idei"51. Sok malinowy może uosabiać witalne siły kobiecości - przypuszczalne lekarstwo na kryzys patriarchatu. Zauważmy, że już w pierwszym rozdziale Sklepów cynamonowych spojrzenie małego Józefa przykuwa gruby, okrągły słój z sokiem malinowym, stojący na aptecznym oknie.

Jednak żaden z prozatorskich tomów Schulza - mimo zaznaczenia perspektywy ocalającej - nie kończy się optymistycznie. W Ostatniej ucieczce (Sanatorium pod Klepsydrq̨) ojciec ostatecznie opuszcza rodzinę, ledwo umknąwszy przed skonsumowaniem jako gotowany rak, i uciekając traci - co jest w najwyższym stopniu symboliczne - nogi. Obraz ten robi wielkie wrażenie, zwłaszcza poprzez skonfrontowanie go $\mathrm{z}$ wizerunkiem ojca z pierwszego rozdziału książki. Fantazmat chłopca o nogach ojca, silnych i niewzruszalnych jak kolumny, należy już do przeszłości. Jak już wspominałam, w prozie Schulza występuje jeszcze inna męska postać pozbawiona nóg, kaleki Edzio, który czołga się jak pies przy łóżku Adeli, by gapić się na jej kobiecość. (Ta scena z rozdziału Józio przypomina grafiki Schulza: kobieta spoczywa na sofie, a mężczyzna, zmutowany niemal do zwierzęcej postaci, czołga się u jej stóp). Powracający motyw „utraty nóg” przez postaci męskie można interpretować jako pozbawienie męskiego świata fundamentu oraz przynależnej mu dotąd pozycji i mocy.

Sklepy cynamonowe kończą się apokaliptyczną rzezią. Powracające ptaki, wyhodowane niegdyś przez ojca i przepędzone przez Adelę, zewnętrznie wprawdzie kolorowe, w rzeczywistości zdegenerowane i ślepe - są skazane na zagładę. Okazuje się, że ojciec nie był w stanie dorównać

50 B. Schulz, Wybór esejów.., op. cit., s. 217.

51 Tamże, s. 223. 
kobiecości i stworzyć zdolne do życia istoty. Jego ptaki zostają zdemaskowane jako papierowe imitacje. Te zdegenerowane, słabowite kreatury nie są w stanie zrozumieć ostrzeżeń ojca (co oznacza, że komunikacja międzypokoleniowa została zaburzona, a tradycja przerwana) i zostają ukamieniowane przez bezmyślną tłuszczę.

Opętany przez fantom klęski ojca i przez własne, podskórnie towarzyszące mu poczucie winy podmiot prozy Schulza wkazujący na samego autora pozwala - w obliczu rozległego, wielowarstwowego kryzysu kultury, gospodarki i polityki, „bezdomności transcendentalnej” i przeczuwanej katastrofy - zmartwychwstać zmarłemu już za życia (wraz z kulturą, którą reprezentuje) ojcu-patriarsze. Czyni to $\mathrm{w}$ konwencji co prawda groteskowej, lecz naznaczonej przejmującą czułością, współczuciem i miłością. Dystansuje się wobec ojca, nigdy go jednak nie „zabijając", ponieważ ojciec, czy jest człowiekiem, ptakiem czy rakiem, nie umiera w tej prozie nigdy. Jednocześnie podnosi go do rangi mitu, który jednak wciąż mu się wymyka ${ }^{52}$.

W nostalgiczno-demaskatorskim powrocie do fantazmatu ojca $\mathrm{z}$ czasów dzieciństwa i równoczesnym nastawieniu na zbawienie poprzez sztukę „produkuje” Schulz oryginalną, nieustannie samokomentującą się „księgę”, co do której wyrażal obawy w swej korespondencji ${ }^{53}$ - nie mając jeszcze pojęcia o dobrodziejstwach postmodernistycznych „licencji” - że nie jest dziełem oryginalnym, że uwodzi zewnętrzną ornamentyką, pikanterią i wyrafinowaniem, by ukryć pustkę znaczeniową i plagiatorski charakter. Tworzy „księgę”, w której wszechmocny Autor ewokując w potężnym akcie twórczym wszystkie stylistyczne rejestry rozpadającej się kultury, broni się przeciw własnej niemocy ${ }^{54}$.

\section{Z niemieckiego przetożyła Gabriela Matuszek}

52 Matka natomiast zostaje oskarżona o brak miłości do ojca i wykluczona z zabiegów mityzujących; por. B. Umińsk a, Postać z cieniem, op. cit.

${ }^{53}$ List do Romany Halpernowej, w: B. Schulz, Proza, Kraków 1964, s. 597.

${ }^{54}$ Por. R. Lachmann, Dezentrierte Bilder..., op. cit. 